\title{
Trypanosomatids (Protozoa: Kinetoplastida) in three species of Armored Catfish from Mogi-Guaçu river, Pirassununga, São Paulo, Brazil
}

\author{
Tripanossomatídeos (Protozoa: Kinetoplastida) em três espécies de cascudos do rio Mogi-Guaçu, \\ Pirassununga, São Paulo, Brasil
}

\author{
Julia Pereira Molina ${ }^{1}$; Rubens Riscala Madi²; Vera Nisaka Solferini ${ }^{3}$; Paulo Sérgio Ceccarellii \\ Hildete Prisco Pinheiro'; Marlene Tiduko Ueta ${ }^{1 *}$
}

\begin{abstract}
${ }^{1}$ Departamento de Biologia Animal, Instituto de Biologia, Universidade Estadual de Campinas - UNICAMP, Campinas, SP, Brasil
${ }^{2}$ Laboratório de Biologia Tropical, Instituto de Tecnologia e Pesquisa, Universidade Tiradentes - UNIT, Aracaju, SE, Brasil

${ }^{3}$ Laboratório de Diversidade Genética, Departamento de Genética e Evolução e Bioagentes, Instituto de Biologia, Universidade Estadual de Campinas - UNICAMP, Campinas, SP, Brasil

${ }^{4}$ Centro de Pesquisa e Gestão dos Recursos Pesqueiros Continentais - CEPTA, Instituto Chico Mendes de Conservação da Biodiversidade - ICMBio, Pirassununga, SP, Brasil

${ }^{5}$ Instituto de Matemática, Estatística e Computação Científica, Universidade Estadual de Campinas - UNICAMP, Campinas, SP, Brasil
\end{abstract}

Received September 29, 2015

Accepted November 13, 2015

\begin{abstract}
Trypanosome infections have been reported in several species of fish, in majority of cases described on the basis of morphological characteristics. Trypanosomes in fish are heteroxenous and transmitted by hirudineans. This study aims to evaluate the prevalence and density of infections by Trypanosoma sp. in blood from three species of catfish, Hypostomus regani, H. strigaticeps, H. albopunctatus, from the Mogi Guaçu River, Pirassununga, São Paulo, Brazil. Further, this study intends to characterize the Trypanosoma specimens found in the blood of these fish by morphological and molecular techniques. The trypanosomes overall prevalence observed was $47.6 \%$ with a general average density of 0.75 parasites $/ \mu \mathrm{l}$ of blood. Hypostomus regani and Hypostomus strigaticeps showed a significant difference in prevalence. The average densities of parasites were not significantly different among the three fish species. Similar findings were observed for the monthly variations in densities. The parasites found in the three species of catfish studied showed similar morphological characteristics. The morphological data and the statistical analyses used in this study didn't show the formation of groups. The analyses provided evidence of the presence of pleomorphisms in the trypanosomes found in the three studied fish.

Keywords: Trypanosoma, fish, Hypostomus, catfish, protozoa.

\section{Resumo}

Infecçóes por tripanossomas foram descritas em diversas espécies de peixes, sendo a maioria das descriçóes baseada nas características morfológicas. Tripanossomas de peixes são heteroxenos e transmitidos por hirudíneos. Este estudo tem como objetivo a avaliação da prevalência e densidade da infecção por Trypanosoma sp. no sangue de três espécies de cascudos, Hypostomus regani, H.strigaticeps, H.albopunctatus, do Rio Mogi-Guaçu, Pirassununga, São Paulo, Brasil. Além disso, pretende-se a caracterização das espécies de Trypanosoma encontradas no sangue desses peixes, por meio da utilização de técnicas morfólogicas e moleculares. A prevalência total de tripanossomas foi de 47,6\%, e a densidade média foi de 0,75 parasitas/ $\mu \mathrm{l}$ de sangue. Hypostomus regani e Hypostomus strigaticeps apresentaram diferenças significativas em prevalência. As médias das densidades dos parasitas não apresentaram diferenças significativas entre as três espécies de peixes estudadas. $\mathrm{O}$ mesmo foi observado com a variação mensal das densidades. Os parasitas encontrados nas três espécies de cascudo possuíam características morfológicas semelhantes. As análises morfológicas e estatísticas obtidas neste estudo não mostraram a formação de grupos. As análises evidenciaram a presença de pleomorfismo dos tripanossomas encontrados nas três espécies de peixes estudados.
\end{abstract}

Palavras-chave: Trypanosoma, peixes, Hypostomus, cascudos, protozoários.

\footnotetext{
*Corresponding author: Marlene Tiduko Ueta. Laboratório de Helmintologia, Departamento de Biologia Animal, Instituto de Biologia, Universidade Estadual de Campinas - UNICAMP, Rua Monteiro Lobato, 255, Bloco J, CEP 13083-862, Campinas, SP, Brasil. e-mail: mtu@unicamp.br
} 


\section{Introduction}

Fish trypanosomes have been observed on several continents, and numerous species have been described in salt and freshwater fish (LOPES et al., 1990; EIRAS, 1994).

For fish trypanosomes, the hirudinean aquatic leech is the only known vector host. Fish become infected with trypanosomes during blood feeding by the invertebrate host. There is no evidence of fish infection from the ingestion of infected leeches (BECKER, 1977; LOM, 1979).

Trypanosomes in the blood of infected fish pass through a series of morphological transformations after ingestion by leeches; this transformation process includes the amastigote, espheromastigote, epimastigote, and trypomastigote forms. Soon after the ingestion of infected blood, the flagellates begin to divide in the stomachs of hirudineans (LOM, 1979; LOM \& DYKOVA, 1992; EIRAS, 1994; EIRAS et al., 2008).

This sequence of forms is directly related to the level of digestion of the ingested blood, and in most cases, the trypomastigote form appears only when the blood has been fully digested. The hirudinean becomes infectious when the trypanosomes reach the metacyclic trypomastigote form and migrate to the mouthparts of the animal, a process that can last from three to nineteen days (LOM, 1979).

The pathogenicity caused by hirudineans can be more than a simple hemorrhage at the feeding site, where the hirudinean attaches. In severe cases of infections, the leeches can cause anemia and even death of the host (ISLAM \& WOO, 1991; WOO, 1995; THATCHER, 2006).

Fish that have recovered from trypanosome infections can develop immunity against re-infection. Thus, the status of the host immune system is an important factor (ISLAM \& WOO, 1991; WOO, 1995; OVERATH et al., 1999).

Currently, 59 species belonging to gender Trypanosoma have been described in infections of fresh and saltwater fish in Brazil (RIBEIRO et al., 1993). The most significantly affected fish family, with respect to the presence of parasites, is the Loricariidae family, of which 33 species are confirmed to belong to the genus Hypostomus and are thus considered to be the most common host (RIBEIRO et al., 1990a). The prevalence of infections in catfish might be due to semi-sedentary habits that enable greater rates of infections by ectoparasites, which in turn transmit the protozoans (FROÉS et al., 1978).

Members of the Loricariidae family are widely distributed and are significantly present in the Paraná basin as well as in the San Francisco basin in Brazil (GARAVELLO \& GARAVELLO, 2004; BUCKUP et al., 2007).

The pathogenesis of fish trypanosomiases is not well known. The parasites live in relative equilibrium with their hosts, which present with low levels of parasitemia. However, changes in the hematological parameters have been observed (BECKER, 1977; EIRAS et al., 1990; EIRAS et al., 2008).

The large variety of hosts, the wide geographic distribution, and the morphometry of parasites represent problems for the descriptions of new species of fish trypanosomes. The identification of new species is also difficulted because trypanosomes exhibit polymorphisms (FRÓES et al., 1978), and the taxonomic identification of fish trypanosome species is furthermore based on differences in the morphological characteristics of the parasites (LOPES et al., 1989; EIRAS et al., 1990).

The traditional taxonomy of Trypanosoma species cannot be used as a reliable method for the determination of new species as it is based on morphological differences of trypomastigote forms in the bloodstream. Molecular techniques have been showed as more effective when applied toward the taxonomic determinations to identification of trypanosomes (FIGUEROA et al., 1999; KARLSBAKK \& NYLUND, 2006; GU et al., 2007a, b).

Studies of fish trypanosomes can assist in finding solutions to important problems that are common to the studies of the pathogenicity caused by these parasites in mammals. Additionally, such studies will contribute to the phylogeny of the group (LOM, 1979).

The occurrence of parasites in fish under natural conditions can be harmless and might not cause pathogenic alterations; however, in culture conditions the parasitic infections can interfere with the health of the host. Hence, it is important to know which parasites affect fishes species with potential to be farmed, due these infections might cause economical losses of this growing fish farming industry in Brazil.

\section{Objectives}

The objectives of this study were to characterize the prevalence and densities of infection by Trypanosoma sp. in blood from Hypostomus albopunctatus, Hypostomus regani, and Hypostomus strigaticeps, which were collected from the Mogi Guaçu River, Pirassununga, São Paulo, Brazil; and to characterize morphologically the specimens of Trypanosoma that were found in blood from catfish and hirudinean vectors.

\section{Materials and Methods}

Monthly collections were performed in the Mogi Guaçu River, Emas Waterfall, in the city of Pirassununga, São Paulo, between February 2008 and February 2009. The fishes, Hypostomus albopunctatus, Hypostomus regani, and Hypostomus strigaticeps, were collected with the aid of nets and were kept in circular $1,000 \mathrm{~L}$ tanks at the Center for Research and Management of Continental Fisheries Resources of the Chico Mendes Biodiversity Conservation Institute - CEPTA/ICMBio. The fishes were tagged with numbered plastic tubular labels and biometric measurements were taken before blood collection.

According to the known blood smears technique, blood samples were obtained via cardiac puncture, been obtained five aliquots, each one with $8 \mu \mathrm{l}$, used to make thick-film smear slides, that were fixed in methanol and stained with Giemsa.

The morphological characteristics of trypomastigote were evaluated and measured from images captured using Leica Image Manager IM $50^{\circ}$ software. The following parameters were analyzed: body length $(\mathrm{BL})$, free flagella length $(\mathrm{FF})$, distance between the posterior portion and the nucleus $(\mathrm{PN})$, distance between the anterior portion and the nucleus (AN), body width (LC), nucleus width (LN), nucleus length $(\mathrm{CN})$, nucleus area (NRA), 
kinetoplast width (LK), kinetoplast length (CK), distance between the kinetoplast and the posterior extremity (DKP), kinetoplast area (ArK), flagellar index (IF), nuclear index (IN), nuclear volume $(\mathrm{VN})$, and kinetoplast volume (VK).

The prevalence and densities were calculated according to the criteria defined by Bush et al. (1997). The Pearson's correlation coefficient were calculated between the densities, weights, and lengths of each fish species. The statistical tests for correlation were performed with a level of significance of $5 \%$.

ANOVA test were performed for each of the morphological variables (BL, FF, PN, AN, LC, LN, CN, Nra, LK, CK, DKP, ArN, IF, IN, VN and VK) using a log transformation in order to achieve normality. For those variables with significant results for the difference of species in the ANOVA tests, the Tukey's multiple comparisons procedure were applied with a combined significance level of $5 \%$.

Multivariate analyses (JOHNSON \& WICHERN, 2007) were performed using PCA (principal component analysis) and cluster analysis. Due to high percentage of missing values (> 50\%), the variables (FF, IF, DKP) were excluded from the multivariate analysis. In order to get a better appoximation to the normal, a log-transformation off all the variables was used. Is also important say that each component is a linear combination of all original variables, in such away that all components are independent.

All statistical analyses were performed using SAS statistical software (SAS Inc., 9.3).

\section{Results and Discussion}

Of the 256 collected catfish, 60 were classified as Hypostomus albopunctatus (average weight of $288.1 \mathrm{~g}$, with standard deviation of $71.4 \mathrm{~g}$; and average length of $28.6 \mathrm{~cm}$, with standard deviation of $2.7 \mathrm{~cm}$ ), 100 were classified as Hypostomus regani (average weight of $322.5 \mathrm{~g}$, with standard deviation of $76.3 \mathrm{~g}$; and average length of $29.6 \mathrm{~cm}$, with standard deviation of $2.5 \mathrm{~cm}$ ), and 96 were classified as Hypostomus strigaticeps (average weight of $281.0 \mathrm{~g}$, with standard deviation of $87.9 \mathrm{~g}$, and average length of $27.3 \mathrm{~g}$, with standard deviation of $3.1 \mathrm{~cm}$ ). One hundred and twenty two fishes were positive under laboratory analysis for Trypanosoma sp., resulting in an overall prevalence of $47.6 \%$ and an overall average density of 0.75 parasites $/ \mu$ l of blood (standard deviation 0.75 ).

In this study, an analysis of Trypanosoma sp. infections by individual species of fishes demonstrated the following prevalence and density results: for Hypostomus albopunctatus, $46.6 \%$ and 0.63 parasites $/ \mu \mathrm{l}$ of blood (standard deviation = 0.46); for Hypostomus regani, $44.0 \%$ and 0.78 parasites $/ \mu$ l of blood (standard deviation $=0.63$ ); and for Hypostomus strigaticeps, $52.0 \%$ and 0.78 parasites/ $\mu \mathrm{l}$ of blood (standard deviation $=0.98)$.

Two hundred and fifty-five parasites from fishes specimens were found, photographed, and measured in the photomicroscope, as follow: 66 from $H$. albopunctatus, 64 from $H$. regani, and 95 from $H$. strigaticeps. Averages of the measured morphological parameters in the parasites from the three species of fish in the study are showed at Table 1 .

The traditional taxonomic identification of fish trypanosome species is based on the morphological characteristics of the parasites. To facilitate morphological description of blood flagelates, morphometrical data were used to divide bloodstream trypomastigotes into morphotypes. The comparative morphological values of the parasites that were observed in the three studied species and in other fishes species are shown on Table 2. An analysis of variance for each of the variables was performed to verify if there are differences among the three species. The results showed that only for CC and LN there are significant differences (by a 0,05 level Tukey's) between species, where $H$. strigaticeps and $H$. albopunctatus were the same and $H$. regani appear different. Multiple comparisons test were performed and our data set didn't form properly groups. The protozoa measurements obtained from the three species of catfish studied, showed that from the species $H$. regani, $H$. strigaticeps and $H$. albopunctatus were probably belonging to different species (called here Trypanosoma morphotype I, Trypanosoma morphotype II, Trypanosoma morphotype III), this according only considering morphometric analyses showed in Table 1 Lemos et al. (2015) used body length and width to separate the flagelates found in the study in different morphotypes. According to Davies et al. (2005), the nucleus location, which is determined by the distance

Table 1. Average values (in $\mu \mathrm{m}$ ) of the measured parameters in the trypanosomes that were observed in three species of catfish collected between February 2008 and February 2009, in Mogi Guaçu River, Pirassununga, São Paulo, Brazil.

\begin{tabular}{|c|c|c|c|c|c|c|c|c|c|c|c|c|c|c|c|c|}
\hline SPECIE & BL & FF & PN & AN & BW & KW & $\mathrm{NuW}$ & $\mathrm{NuL}$ & NI & $\begin{array}{l}\mathrm{Nu}- \\
\text { area }\end{array}$ & DKP & KL & Karea & FI & NV & KV \\
\hline $\begin{array}{l}\text { Hypostomus } \\
\text { albopunctatus }\end{array}$ & 29.02 & 11.50 & 16.52 & 10.64 & 1.96 & 0.61 & 1.43 & 2.85 & 1.71 & 4.07 & 0,45 & 1.02 & 0.55 & 2.90 & 5.64 & 0.28 \\
\hline SD & \pm 10.94 & \pm 6.24 & \pm 5.85 & \pm 5.83 & \pm 0.72 & \pm 0.17 & \pm 0.54 & \pm 1.06 & \pm 0.45 & \pm 3.36 & $\pm 0,14$ & \pm 0.26 & \pm 0.36 & \pm 0.89 & \pm 6.61 & \pm 0.19 \\
\hline $\begin{array}{l}\text { Hypostomus } \\
\text { regani }\end{array}$ & 24.73 & 15.45 & 14.98 & 8.71 & 1.94 & 0.58 & 1.59 & 2.96 & 1.88 & 4.72 & 0,33 & 0.95 & 0.52 & 1.95 & 5.79 & 0.24 \\
\hline SD & \pm 5.76 & \pm 6.06 & \pm 3.30 & \pm 3.06 & \pm 0.45 & \pm 0.17 & \pm 0.37 & \pm 0.65 & \pm 0.68 & \pm 1.98 & $\pm 0,19$ & \pm 0.20 & \pm 0.23 & \pm 1.15 & \pm 3.17 & \pm 0.16 \\
\hline $\begin{array}{l}\text { Hypostomus } \\
\text { strigaticeps }\end{array}$ & 25.01 & 11.70 & 15.12 & 9.43 & 1.93 & 0.63 & 1.50 & 2.81 & 1.78 & 4.08 & 0,41 & 0.97 & 0.65 & 2.87 & 5.82 & 0.29 \\
\hline SD & \pm 7.74 & \pm 6.20 & \pm 4.57 & \pm 4.40 & \pm 0.52 & \pm 0.21 & \pm 0.55 & \pm 0.77 & \pm 0.61 & \pm 3.42 & $\pm 0,23$ & \pm 0.24 & \pm 0.80 & \pm 1.77 & \pm 9.03 & \pm 0.29 \\
\hline
\end{tabular}

Body length (BL), free flagella length (FF), distance between the posterior portion and the nucleus (PN), distance between the anterior portion and the nucleus (AN), body width (LC), nucleus width (LN), nucleus length (CN), nucleus area (NRA), kinetoplast width (LK), kinetoplast length (CK), distance between the kinetoplast and the posterior extremity (DKP), kinetoplast area (ArK), flagellar index (IF), nuclear index (IN), nuclear volume (VN), and kinetoplast volume (VK). Averages followed by the same letter are not significantly different. SD: standard deviation. 
Table 2. Morphometry of the species of Trypanosoma sp. as described in different species of fish collected between February 2008 and February 2009, in Mogi Guaçu River, Pirassununga, São Paulo, Brazil. The featured species refer to the present study.

\begin{tabular}{|c|c|c|c|c|c|c|c|c|c|c|c|c|c|}
\hline SPECIE & BL & BW & FF & PN & $\mathrm{AN}$ & KW & VK & $\mathrm{NuW}$ & $\mathrm{NuL}$ & IN & VN & HOST & Reference \\
\hline T. nupelianus & 17.60 & 2.18 & 12.70 & 13.77 & 12.10 & 0.75 & 0.28 & 1.20 & 3.10 & 1.14 & 3.96 & Rhinelepis aspera & Eiras et al. (1990) \\
\hline T. pradoi I & 20.20 & 1.57 & 8.77 & 9.63 & 10.57 & 0.67 & 0.67 & 1.23 & 2.10 & 0.91 & 2.34 & $\begin{array}{l}\text { Hypostomus } \\
\text { ancistroides }\end{array}$ & Ribeiro et al. (1993) \\
\hline T. plecostomi I & 21.50 & 2.30 & 14.00 & 12.00 & - & 0.50 & - & 2.10 & 2.90 & - & - & Hypostomus sp. & $\begin{array}{c}\text { Fonseca \& Vaz } \\
\quad(1928)\end{array}$ \\
\hline T. strigaticeps $I$ & 21.90 & 3.20 & 12.00 & 12.50 & - & 0.60 & - & 2.10 & 2.50 & - & - & Hypostomus sp. & $\begin{array}{c}\text { Fonseca \& Vaz } \\
\quad(1928)\end{array}$ \\
\hline T. regani II & 23.10 & 1.90 & 12.30 & 13.10 & - & 0.50 & - & 1.90 & 3.00 & - & - & Hypostomus sp. & $\begin{array}{c}\text { Fonseca \& Vaz } \\
\quad(1928)\end{array}$ \\
\hline T. strigaticeps II & 23.50 & 2.00 & 12.00 & 15.00 & - & 0.50 & - & 2.00 & 2.60 & - & - & Hypostomus sp. & $\begin{array}{c}\text { Fonseca \& Vaz } \\
\quad(1928)\end{array}$ \\
\hline $\begin{array}{l}\text { Trypanosoma } \\
\text { Morphotype I }\end{array}$ & 24.73 & 1.94 & 15,45 & 14,98 & 8.71 & 0.58 & 0.24 & 1.59 & 2.96 & 1.88 & 5.79 & H. regani & This study \\
\hline $\begin{array}{l}\text { Trypanosoma } \\
\text { Morphotype II }\end{array}$ & 25,01 & 1,93 & 11,70 & 15,12 & 9,43 & 0,63 & 0,29 & 1,50 & 2,81 & 1,78 & 5,82 & H. strigaticeps & This study \\
\hline T. dominguesi & 25.50 & 2.10 & 9.40 & 13.70 & 12.30 & 0.70 & 0.18 & 1.40 & 3.90 & 1.10 & 7.29 & Hypostomus alatus & Lopes et al. (1989) \\
\hline T. itoi I & 25.88 & 2.18 & 12.70 & 13.77 & 12.10 & 0.75 & 0.28 & 1.20 & 3.10 & 1.14 & 3.96 & Hypostomus sp. & Ribeiro et al. (1990b) \\
\hline $\begin{array}{l}\text { Trypanosoma } \\
\text { Mosphotype III }\end{array}$ & 29.02 & 1.92 & 11.50 & 16.52 & 10.64 & 0.61 & 0.28 & 1.43 & 2.85 & 1.71 & 5.64 & H. albopunctatus & This study \\
\hline T. lopesi & 31.95 & 2.50 & 6.40 & 19.50 & 4.55 & 0.70 & 0.20 & 1.30 & 3.45 & 2.35 & 7.60 & Rhinelepis aspera & Ribeiro et al. (1989) \\
\hline T. barretoi & 36.20 & 3.87 & 14.12 & 19.65 & 16.65 & 0.78 & 0.41 & 2.65 & 4.40 & 1.22 & 40.37 & $\begin{array}{l}\text { Hypostomus } \\
\text { paulinus }\end{array}$ & Lopes et al. (1990) \\
\hline T. itoi II & 43.77 & 3.40 & 11.17 & 21.76 & 22.00 & 0.84 & 0.38 & 1.80 & 3.57 & 0.99 & 8.89 & Hypostomus sp. & Ribeiro et al. (1990b) \\
\hline T. pintoi & 45.10 & 3.30 & 12.00 & 25.30 & 19.80 & 0.80 & 0.46 & 2.20 & 4.20 & 1.30 & 14.40 & Hypostomus sp. & Ribeiro et al. (1990b) \\
\hline T. regani $I V$ & 46.10 & 3.30 & 16.60 & 23.30 & - & 0.90 & - & 3.10 & 4.60 & - & - & Hypostomus sp. & $\begin{array}{c}\text { Fonseca \& Vaz } \\
\quad(1928)\end{array}$ \\
\hline T. pradoi II & 47.58 & 3.47 & 17.17 & 25.62 & 21.97 & 0.75 & 0.75 & 2.53 & 4.97 & 1.17 & 19.32 & $\begin{array}{l}\text { Hypostomus } \\
\text { ancistroides }\end{array}$ & Ribeiro et al. (1993) \\
\hline T. regani $V$ & 49.50 & 2.60 & 16.00 & 24.20 & - & 0.80 & - & 2.60 & 4.30 & - & - & Hypostomus sp. & $\begin{array}{c}\text { Fonseca \& Vaz } \\
\quad(1928)\end{array}$ \\
\hline T. petenuscii & 50.10 & 3.40 & 12.80 & 26.70 & 23.10 & 0.80 & 0.30 & 3.00 & 5.00 & 1.20 & 30.50 & Hypostomus sp. & Carraro et al. (1992) \\
\hline T. barrosi & 53.90 & 3.30 & 19.80 & 30.90 & 22.70 & 0.90 & 0.20 & 2.80 & 4.60 & 1.40 & 34.90 & Hypostomus sp. & Ribeiro et al. (1992) \\
\hline T. lamanoi & 56.70 & 3.10 & 13.70 & 30.30 & 26.40 & 1.10 & 0.30 & 3.10 & 5.00 & 1.10 & 35.40 & $\begin{array}{l}\text { Hypostomus } \\
\text { ancistroides }\end{array}$ & Costa et al. (1992) \\
\hline T. birmanii I & 57.20 & 3.80 & 9.40 & 30.30 & 26.90 & 0.90 & 0.43 & 2.50 & 4.90 & 1.10 & 27.30 & $\begin{array}{l}\text { Hypostomus } \\
\text { commersonii }\end{array}$ & Ribeiro et al. (1991) \\
\hline T. affonsoi & 57.80 & 3.60 & 16.70 & 30.30 & 27.50 & 0.80 & 0.39 & 2.80 & 3.80 & 1.10 & 19.60 & $\begin{array}{l}\text { Hypostomus } \\
\text { tietensis }\end{array}$ & Lopes et al. (1992) \\
\hline T. birmanii II & 59.20 & 4.50 & 14.40 & 31.30 & 27.80 & 1.00 & 0.46 & 2.60 & 5.60 & 1.10 & 42.40 & $\begin{array}{l}\text { Hypostomus } \\
\text { commersonii }\end{array}$ & Ribeiro et al. (1991) \\
\hline T. birmanii III & 59.20 & 4.50 & 14.40 & 31.30 & 27.80 & 1.00 & 0.50 & 2.60 & 5.60 & 1.10 & 42.40 & $\begin{array}{l}\text { Hypostomus } \\
\text { commersonii }\end{array}$ & Ribeiro et al. (1991) \\
\hline T. zungaroi IV & 61.50 & 9.00 & 0.00 & 32.00 & - & 7.00 & - & 4.50 & 5,50 & - & - & $\begin{array}{l}\text { Pseudopmelodus } \\
\text { zungaro }\end{array}$ & $\begin{array}{c}\text { Fonseca \& Vaz } \\
\quad(1928)\end{array}$ \\
\hline T. limae & 66.64 & 3.81 & 11.22 & 39.58 & 27.05 & 1.33 & 0.42 & 3.40 & 5.49 & 1.46 & 41.52 & Hoplias lacerdae & Lopes et al. (1996) \\
\hline $\begin{array}{l}\text { T. venustissimum } \\
\text { II }\end{array}$ & 71.50 & 2.60 & 3.50 & - & - & 1.00 & - & - & 3.00 & 1.30 & - & $\begin{array}{l}\text { Plecostomus } \\
\text { plecostomus }\end{array}$ & Froés et al. (1979) \\
\hline T. immanis II & 114.50 & - & 6.00 & - & - & 0.70 & - & - & - & 1.20 & - & $\begin{array}{c}\text { Loricariichthys } \\
\text { anus }\end{array}$ & Froés et al. (1978) \\
\hline T. immanis I & 125.60 & 3.80 & 7.00 & - & - & 1.20 & - & - & - & 1.00 & - & $\begin{array}{c}\text { Loricariichthys } \\
\text { anus }\end{array}$ & Froés et al. (1978) \\
\hline
\end{tabular}

Body length (BL), free flagella length (FF), distance between the posterior portion and the nucleus (PN), distance between the anterior portion and the nucleus (AN), body width (LC), nucleus width (LN), nucleus length (CN), nucleus area (NRA), kinetoplast width (LK), kinetoplast length (CK), distance between the kinetoplast and the posterior extremity (DKP), kinetoplast area (ArK), flagellar index (IF), nuclear index (IN), nuclear volume (VN), and kinetoplast volume (VK). Averages followed by the same letter are not significantly different. SD: standard deviation. 
between the anterior extremity and the nucleus, is a significant factor for the discrimination of three species of fish trypanosomes reported in Africa (T. mukasai (Hoare, 1932); T. toddi (Bouet, 1909); T. tobeyi (Dias, 1952)). The results shown in the ANOVA described previously were the same as the result obtained in the principal component analysis (PCA). From Figure 1 we can see that with only two components of PCA, 65\% of the variability of the data can be explained. The PCAs test showed no grouping of the three species (Figure 2). Multivariate analysis supports no group formation. The results of cluster analyses also showed no formation of groups properly. In the cluster analyses we found 172 groups from our total of 256 elements, wich support the findings from the other analyses.

\begin{tabular}{|r|c|l|r|r|}
\hline \multicolumn{5}{|c|}{ Eigenvalues of the Correlation Matrix } \\
\hline & Eigenvalue & Difference & Proportion & Cumulative \\
\hline $\mathbf{1}$ & 5.32293369 & 2.18304055 & 0.4095 & 0.4095 \\
\hline $\mathbf{2}$ & 3.13989313 & 1.67696976 & 0.2415 & 0.6510 \\
\hline
\end{tabular}

Figure 1. Eingenvalues of the correlation matrix of the principal component procedure showing the percentage of explanation of the data variability.
The parasites observed in the three fish species in this study, showed the following morphological characteristics: polymorphisms, dense cytoplasm, clearly visible elliptical nuclei with sharp contours, touching or not the edges of the body and loose chromatin, and terminal and clear kinetoplasts that were located at an average distance of $0.40 \mu \mathrm{m}( \pm 0.23)$ from the posterior extremities. The bodies gradually tapered toward both ends. The undulating membranes were evident in majority of evaluated specimens, with variation of number of displayed undulations. Some parasites presented with free, long flagella at the anterior extremity, whereas others did not present free flagella. Two morphologically distinct forms were observed; some parasites presented with a slender and short body shape, while others presented with a long and wide body shape and diffuse cytoplasm (Figures 3-5). Occurrence frequency was established according to the variations in body length to assist in the analysis of pleomorphism (Figure 6).

The Trypanosoma morphotype I, II and III prevalence values observed in this study are greater than those reported by Khan (1977) for North Atlantic fish, and Burreson (2007) for fish from the Pacific. These values are below those reported by Zintl et al. (1997) for European eels and are similar to those reported by Davies et al. (2005) for freshwater fish from Africa.

The density values observed in this study were above those reported by Khan (1977) for Hippoglossoides platessoides and

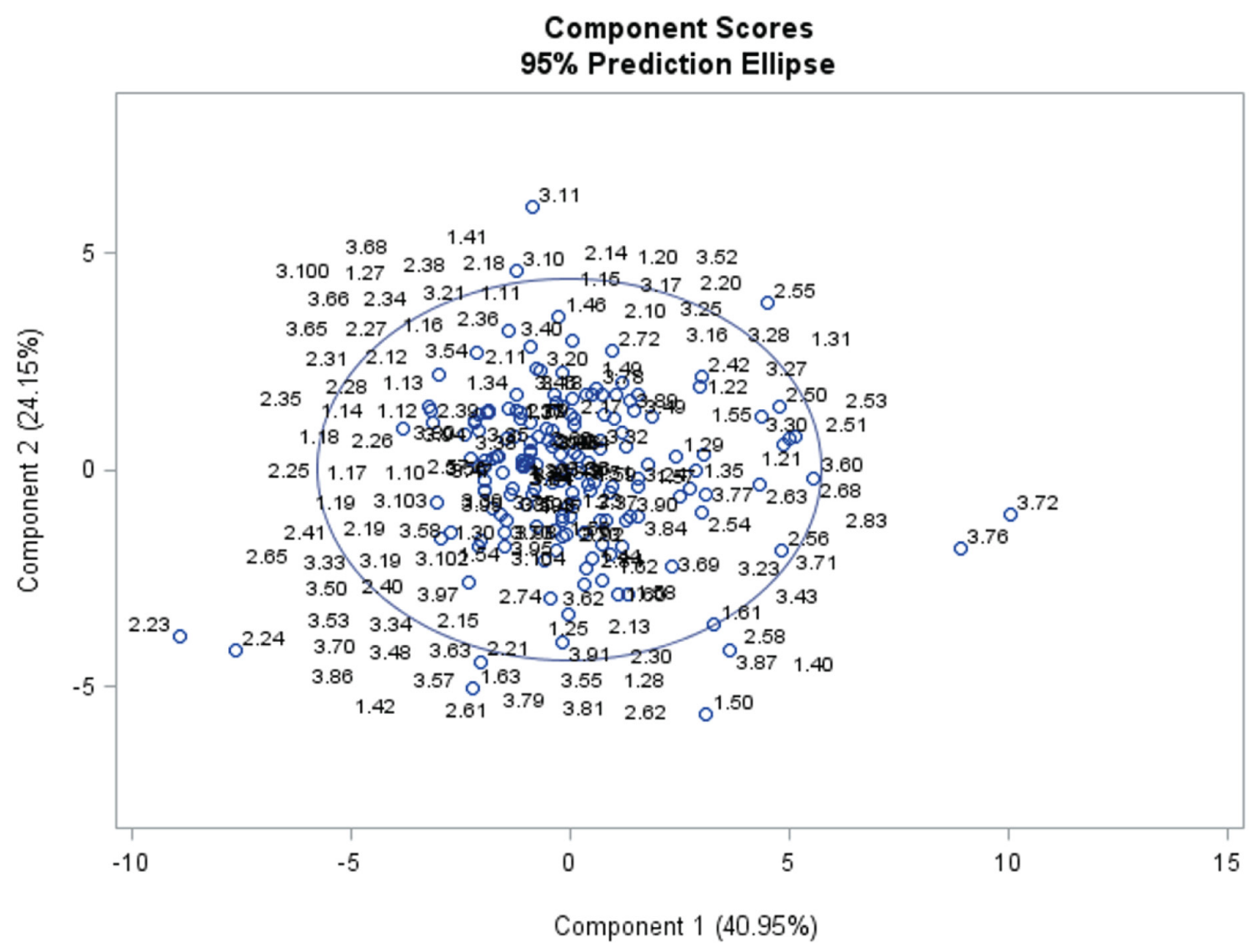

Figure 2. Principal component analyses of the of the measured parameters in the trypanosomes that were observed in three species of catfish collected between February 2008 and February 2009, in Mogi Guaçu River, Pirassununga, São Paulo, Brazil. (Hyposyomus regani called here (1), Hypostomus strigaticeps called here (2) and Hypostomus albopunctatus called here (3)). 
Limanda ferruginea, and below those described by Gu et al. (2007b) for Cyprinus carpio.

The number of studies that describes Trypanosoma species in Loricariidae family is extensive; however, no reference has been reporting the prevalence or densities of these protozoa.
The Trypanosoma morphotype I, II and III using just the morphological data can be considered to different species or can be a pleomorfism of the same species. The statistical analyses could't give an answer about the possibility of this flagellates showing a grouping of species. By definition, pleomorphism is the presence

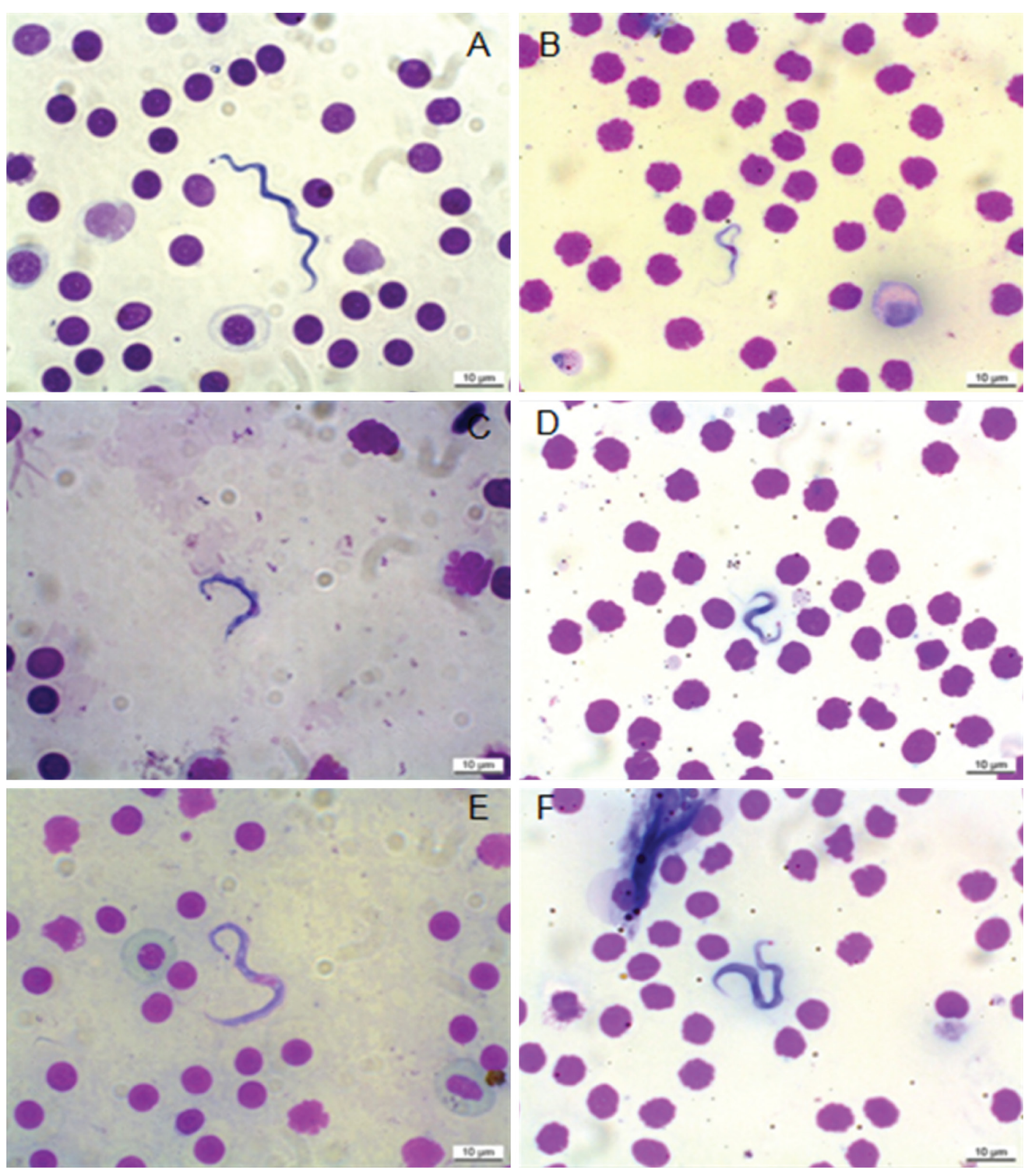

Figure 3. Trypomastigote forms present in the blood of Hypostomus albopunctatus. Amplification 100X. A: Long form; B: Short form; C: Membrane with multiple undulations; D: Membrane with few undulations; E: Specimen with free flagella; F: Specimen without free flagella. 


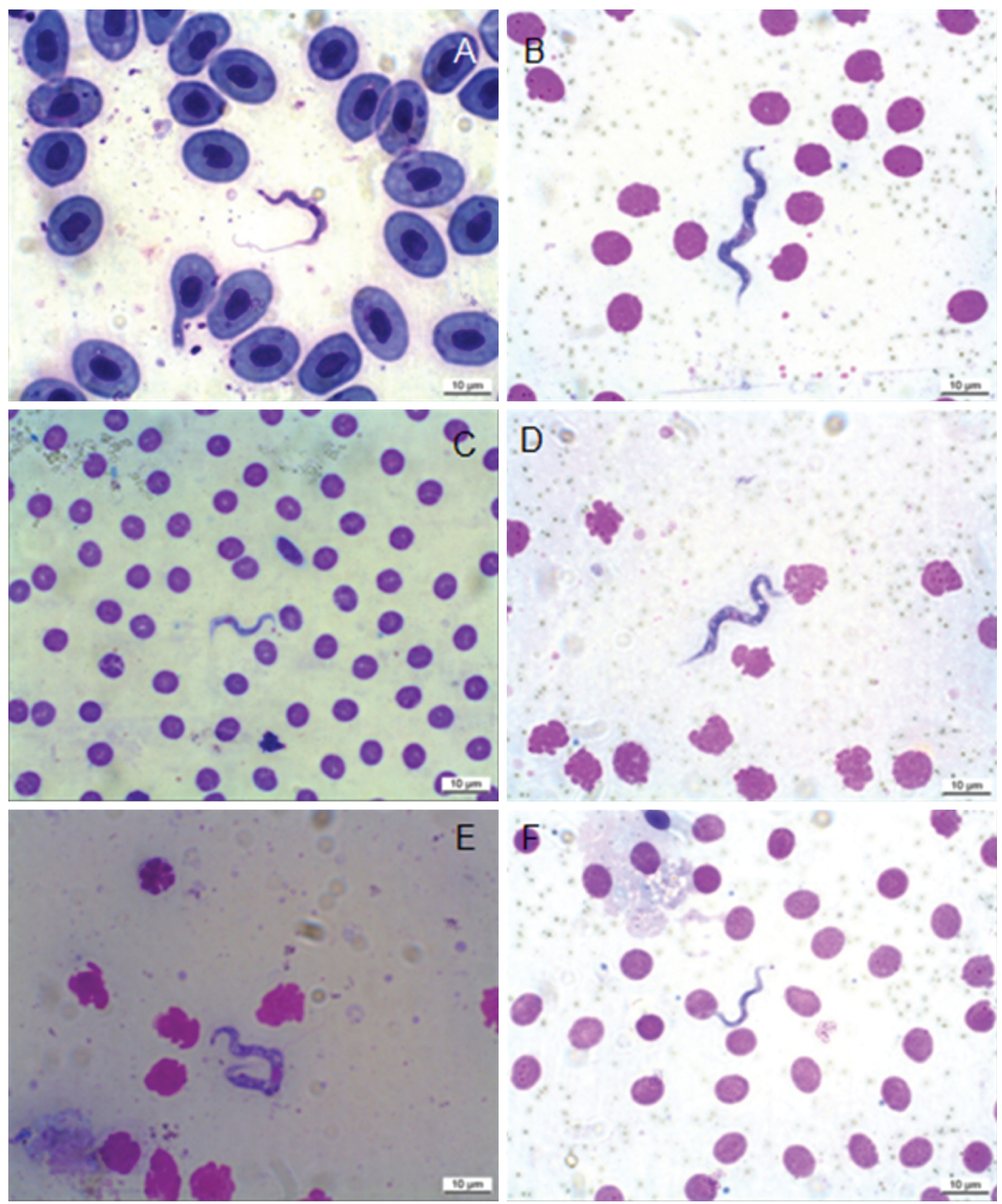

Figure 4. Trypomastigote forms present in the blood of Hypostomus regani. Amplification 100X. A: Specimen with free flagella and membrane with multiple undulations; B: Specimen without free flagella and membrane with few undulations; C: Short form; D: Long form; E: Wide form and with diffuse cytoplasm; F: Slender form and with regular cytoplasm. 


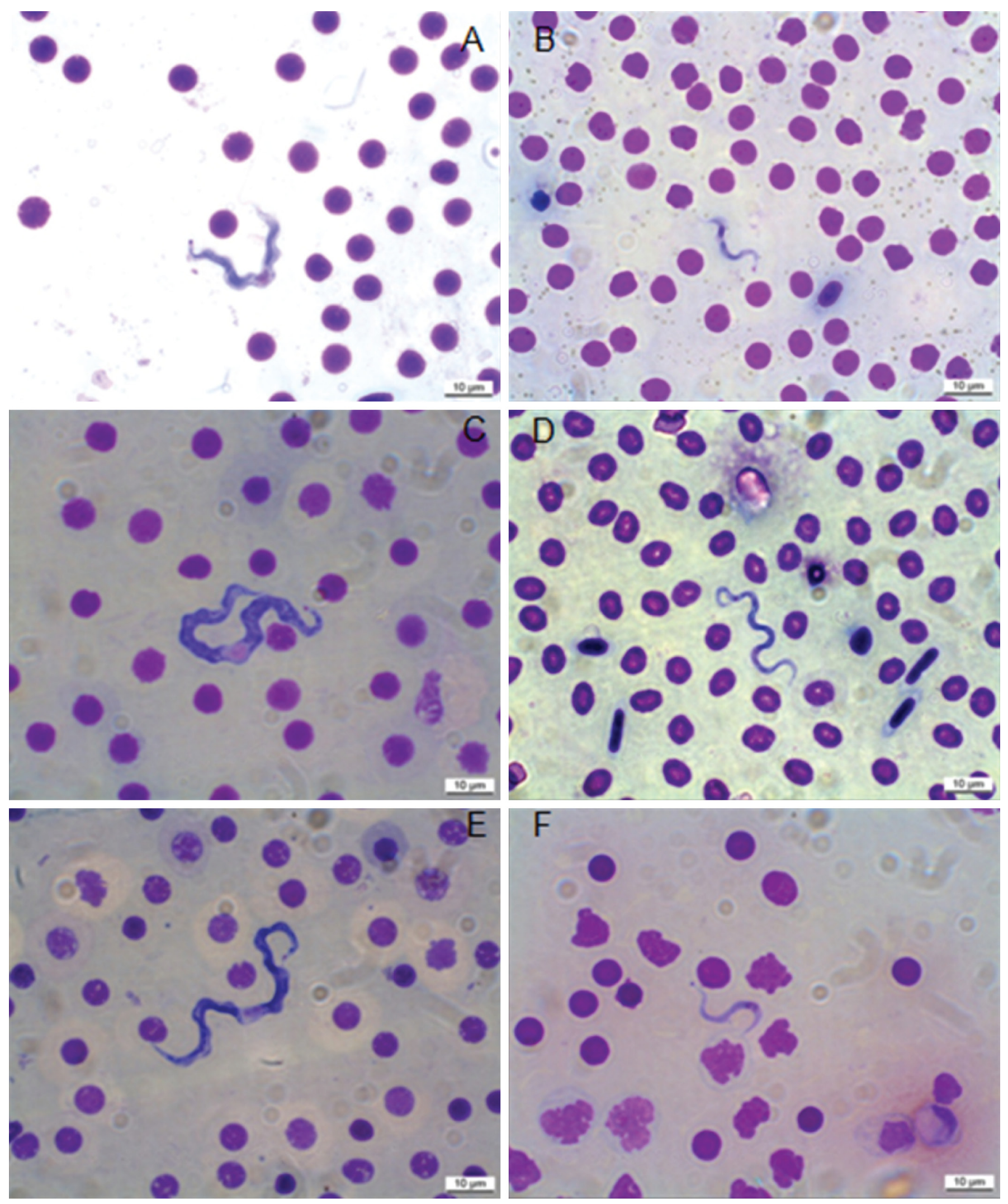

Figure 5. Trypomastigote forms present in the blood of Hypostomus strigaticeps. Amplification 100X. A: Specimen with free flagella and membrane with multiple undulations; B: Specimen without free flagella and membrane with few undulations; C: Wide form and with diffuse cytoplasm; D: Slender form and with regular cytoplasm; E: Long form; F: Short form. 


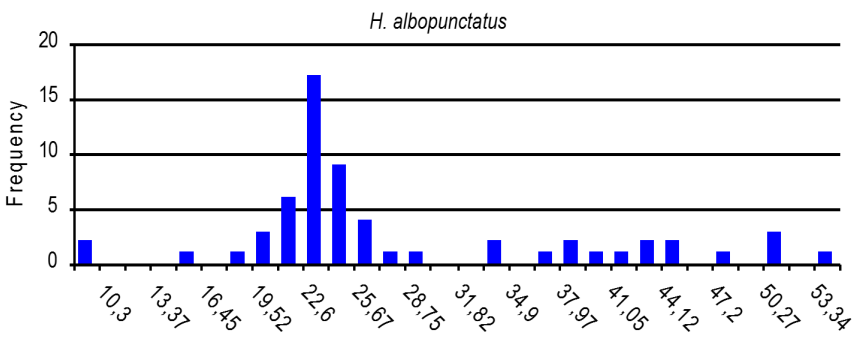

Body length $(\mu \mathrm{m})$

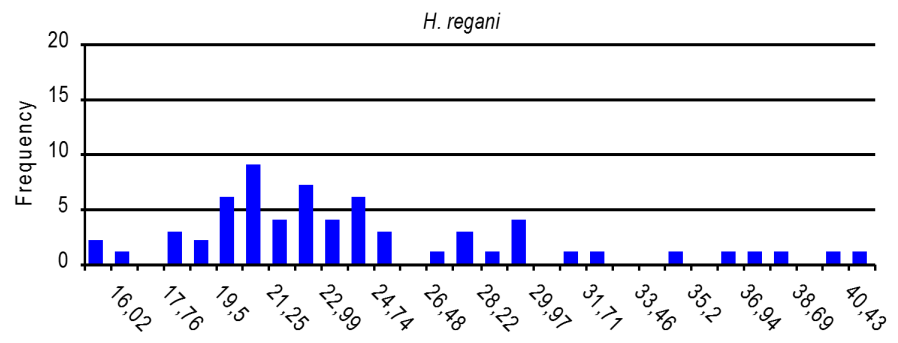

Body length $(\mu \mathrm{m})$

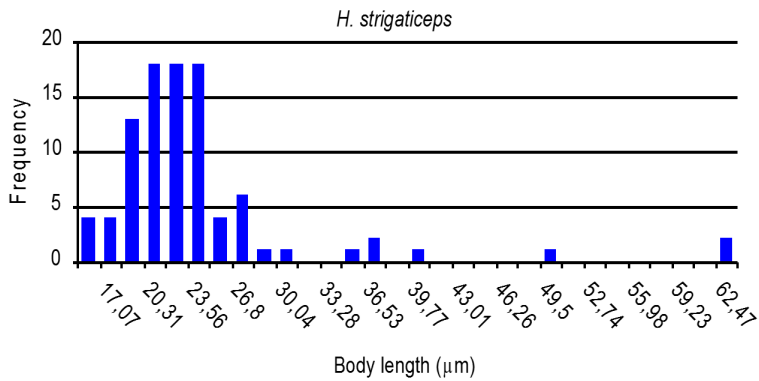

Figure 6. Frequencies distribution of body lengths of trypanosomes that were found in the three studied species of catfish collected between February 2008 and February 2009 at the Mogi Guaçu River, Emas Waterfall, city of Pirassununga, SP.

of various forms of development of a parasite within one host. In blood flagellates from fish, as in other organisms, pleomorphism is understood as a sequential phenotypical manifestation of a genotype that appears in the trypomastigote stage in vertebrate hosts (FERMINO et al., 2015) The pleomorphism can be expressed in the following ways: changes in the total length and width of the body (slender or wider shapes), the number of ripples in the undulating membrane, the presence or absence of a distinct karyosome, the presence of stretch marks on the body surface, the presence and number of cytoplasmic granules, the distance between the kinetoplast and the posterior portion, and the length of the free flagella (LOM, 1979).

According to Gibson et al. (2005), the trypanosomes from freshwater fish found in Europe can be grouped as monomorphic or polymorphic. In the first group, they grouped the parasites showing similar morphologies in the early, acute, and chronic stages of infection, differing only in body length. In the second group, were put the parasites that also showed alterations in length but concomitantly showed variations in body width in the chronic phase of infection.

In a study about the life cycle of Trypanosoma cobitis, Letch (1980) reports that the majority of infected fishes that were captured in natural environments were found to have trypanosomes in the peripheral blood, displayed a wide range of morphologies, which may have been the result of multiple infectious events.

The body length variations that were observed in the analyzed trypanosomes specimens, suggest that the pleomorphism appears to be the way to characterize an already established infection. Some authors state that, during the course of infection, the short and slender forms appear at the very beginning, becoming long and wide with the infection maturation (LOM, 1979; LETCH, 1980). Other authors affirm that the pleomorphism is related to the environmental temperatures, with the short and slender forms appearing during the hottest periods, and long and wide forms appearing during cold periods. In the present study, the differences in the forms of trypanosomes that were observed throughout the year were not characterized as related to environmental temperature or age infection. (WOO, 1994).

Morphologically, the Trypanosoma morphotype II and III showed body-length values greater than the few species already describes in the same gender host. In these specimens also was observed that the distance between the front portion and the nucleus was greater than other species (Table 2), including the other sample characterized as Trypanosoma morphotype I on this study.

The other Trypanosoma morphotype I. described on this study showed body length values $(24.89 \mu \mathrm{m})$ that were smaller than the most already described by others authors (Table 2). The most curious was that this Trypanosoma sp. showed values for all analyzed parameters significantly smaller when compared with $T$. regani $I V$ and $T$. regani $\mathrm{V}$, even when the species were found to infect the same host.

\section{Conclusions}

The statistical analyses used in this study didn't show the formation of groups. The flagellates observed in this study provided evidence for the occurrence of pleomorphism in the trypanosomes that were found in the three species of fishes here studied.

\section{Acknowledgements}

This work was supported by FAPESP. The authors are grateful the Laboratory of Genetic Diversity, Laboratory of Helminthology and CEPTA/ICMBio. (Register number of SISBIO: 5561050). 


\section{References}

Becker CD. Flagellate Parasites of fish. In: Kreier JP. Parasitic Protozoa. vol1. taxonomy, kinetoplastids, and flagellates of Fish. New York: Academic Press; 1977. p. 358-412.

Buckup PA, Menezes NA, Ghazzi MS. Catálogo das espécies de peixes de água doce do Brasil. Rio de Janeiro: Museu Nacional; 2007.

Burreson EM. Hemoflagellates of oregon marine fishes with the description of new species of Trypanosoma and Trypanoplasma. J Parasitol 2007; 93(6): 1442-1451. http://dx.doi.org/10.1645/GE-1220.1. PMid:18314692.

Bush AO, Lafferty KD, Lotz JM, Shostak AW. Parasitology meets ecology on its own terms: Margolis et al. revisited. J Parasitol 1997; 83(4): 575583. http://dx.doi.org/10.2307/3284227. PMid:9267395.

Carraro AA, Lopes RA, Ribeiro RD, Albuquerque S, Watanabe I, Satake T, et al. Tripanossomos de peixes brasileiros XXVII. Trypanosoma petenuscii sp. n. encontrado no cascudo Hypostomus sp. (Pisces, Lorcariidae), capturado no rio Paraná, município de Porto Rico, Estado do Paraná, Brasil. An da IX Jor Paul de Parasitol 1992; 1: 21-22.

Costa JRV, Lopes RA, Ribeiro RD, Satake T, Carraro AA, Albuquerque $\mathrm{S}$, et al. Tripanossomos de peixes brasileiros XXIII. Trypanosoma lamanoi sp. n. encontrado no cascudo Hypostomus ancistroides Hering 1911 (Pisces, Loricaiidae) capturado no açude Fartura, município de São Sebastião da Grama, Estado de São Paulo, Brasil. An da IX Jor Paul de Parasitol 1992; 1: 18-20.

Davies AJ, Gibson WC, Ferris VR, Basson L, Smit NJ. Two genotypic groups of morphologically similar fish trypanosomes from the Okavango Delta, Botswana. Dis Aquat Organ 2005; 66(3): 215-220. http://dx.doi. org/10.3354/dao066215. PMid:16261936.

Eiras JC, Rego AA, Pavanelli GC. Trypanosoma nupelianus sp. n (Protozoa, Kinetoplastida) parasitizing Rhinelepis aspera (Osteichthyes, Loricariidae) from Paraná river, Brazil. Mem Inst Oswaldo Cruz 1990; 85(2): 183-184. http://dx.doi.org/10.1590/S0074-02761990000200006.

Eiras JC, Segner H, Wahli T, Kapoor BG. Fish Diseases. Enfield: Science Publishers; 2008. vol. 1.

Eiras JC. Elementos de Ictioparasitologia. Porto: Ediçôes Afrontamento; 1994.

Fermino BR, Paiva F, Soares P, Tavares LR, Viola LB, Ferreira RC, et al. Field and experimental evidence of a new Caiman Trypanosome species closely phylogenetically related to fish Trypanosomes and transmitted by Leeches. Int J Parasitol 2015; 4(3): 368-378. http://dx.doi.org/10.1016/J. Ijppaw.2015.10.005

Figueroa F, Mayer WE, Lom J, Dyková I, Weller M, Pecková H, et al. Fish trypanosomes: their position in kinetoplastid phylogeny and variability as determined from 12S rRNA Kinetoplat Sequences. J Eukaryot Microbiol 1999; 46(5): 473-481. http://dx.doi.org/10.1111/j.1550-7408.1999. tb06064.x. PMid:10519215.

Fonseca F, Vaz Z. Novos trypanosomas de peixes brasileiros. An Facul Med SP 1928; 3: 69-94.

Froés OM, Fortes E, Lima DF, Leite VRV. Três espécies novas de tripanossomas de água doce do Brasil (Protozoa, Kinetoplastida). Rev Bras Biol 1978; 38: 461-468.

Froés OM, Fortes E, Lima DF, Leite VRV. Tripanossomas (Protozoa, Kinetoplastida) de peixes de água doce do Brasil. II: Novos tripanossomas de cascudos (Pisces, Loricariidae). Rev Bras Biol 1979; 39: 425-429.

Garavello JC, Garavello JP. Spatial distribution and interaction of four species of the catfish genus Hypostomus Lacépède with bottom of Rio São
Francisco, Canindé do São Francisco, Sergipe, Brazil (Pisces, Loricariidae, Hypostominae). Rev Bras Biol 2004; 64(3B): 591-598. PMid:15619997.

Gibson WC, Lom J, Pecková H, Ferris VR, Hamilton PB. Phylogenetic analysis of freshwater fish trypanosomes from Europe using ssu rRNA gene sequences and random amplification of polymorphic DNA. Parasitology 2005; 130(4): 405-412. http://dx.doi.org/10.1017/S0031182004006778. PMid:15830814.

Gu Z, Wang J, Li M, Zhang J, Gong X. Redescription of Trypanosoma siniperca Chang 1964 from freshwater fish of China based on morphological and molecular data. Parasitol Res 2007a; 100(2): 395-400. http://dx.doi. org/10.1007/s00436-006-0355-0. PMid:17063366.

Gu Z, Wang J, Li M, Zhang J, Ke X, Gong X. Morphological and genetic differences of Trypanosoma in some Chinese freshwater fishes: difficulties of species identification. Parasitol Res 2007b; 101(3): 723-730. http:// dx.doi.org/10.1007/s00436-007-0536-5. PMid:17558522.

Islam AKMN, Woo PTK. Anemia and its mechanism in goldfish Carassius auratus infected with Trypanosoma danilewskyi. Dis Aquat Organ 1991; 11(1): 37-43. http://dx.doi.org/10.3354/dao011037.

Johnson RA, Wichern DW. Applied multivariate statical analysis. 6th ed. Upper Saddle River: Prentice Hall; 2007.

Karlsbakk E, Nylund A. Trypanosomes infecting cod Gadus morhua L. In the North Atlantic: a resurrection of Trypanosoma pleuronectidium Robertson, 1906 and delimitation of T. murmanense Nikitin, 1927 (emend.), with a review of other trypanosomes from North Atlantic and Mediterranean teleosts. Syst Parasitol 2006; 65(3): 175-203. http:// dx.doi.org/10.1007/s11230-006-9049-3. PMid:16955339.

Khan RA. Susceptibility of marine fish to trypanosomes. Can J Zool 1977; 55(8): 1235-1241. http://dx.doi.org/10.1139/z77-162. PMid:902173.

Lemos M, Fermino BR, Simas-Rodrigues C, Hoffmann L, Silva R, Camargo EP, et al. Phylogenetic and morphological characterization of trypanosomes from Brazilian armoured catfishes and leeches reveal high species diversity, mixed infections and new fish trypanosome species. Parasit Vectors 2015; 8(1): 573. http://dx.doi.org/10.1186/s13071-0151193-7. PMid:26546294.

Letch CA. The life-cycle of Trypanosoma cobitis Mitrophanow 1883. Parasitology 1980; 80(1): 163-169. http://dx.doi.org/10.1017/ S0031182000000627.

Lom J, Dykova I. Protozoan parasites of fish. In: Lom J, Dykova I. Developments in aquaculture and fisheries science. Amsterdam: Elsevier; 1992. vol. 26.

Lom J. Biology of Trypanosomes and Trypanoplasms of fish. In: Lumsden WHR. Biology of Kinetoplastidae. London: Academic Press; 1979. p. 269-337, vol. 2.

Lopes RA, Albuquerque S, Carraro AA, Satake T, Ribeiro RD, Brentegani LG, et al. Tripanossomos de peixes brasileiros. XXXI. Trypanosoma limae sp. n. encontrado no trairão Hoplias lacerdae, Ribeiro (1908) (Pisces, Erythrinidae), capturado no rio Comandante Fontoura, Estado do Mato Grosso, Brasil. Rev Reg de Ciên 1996; 6: 239-242.

Lopes RA, Ribeiro RD, Satake T, Nuti-Sobrinho A, Garcia TAR. Trypanosomes of Brazilian fishes. II. Trypanosoma barrettoi sp. n. from Hypostomus paulinus (Siluriformes, Loricariidae). Angew Parasitol 1990; 31(1): 11-14. PMid:2337249.

Lopes RA, Ribeiro RD, Zuim SMF, Garavello JC, Carraro AA, Albuquerque $\mathrm{S}$, et al. Tripanossomos de peixes brasileiros. XX. Trypanosoma affonsoi n. sp. encontrado no cascudo Hypostomus tietensis Ihering 1905 (Pisces, Loricariidae), do rio Piracicaba, localidade de Santa Maria da Serra 
(represa de Barra Bonita), Estado de São Paulo, Brasil. An da $44^{\circ}$ reun An da SBPC 1992; 1: 744-745.

Lopes RA, Satake T, Brentegani LG, Nuti-sobrinho A, Britski HA, Ribeiro RD. Trypanosomes of Brazilian fishes. III. Trypanosoma dominguesi sp. n. from armored catfish Hypostomus alatus Castelnau 1855 (Pisces, Loricariidae). Ann Parasitol Hum Comp 1989; 64: 83-88.

Overath P, Haag J, Mameza MG, Lischke A. Freshwater fish trypanosomes: definition of two types, host control by antibodies and lack of antigenic variation. Parasitology 1999; 119(6): 591-601. http://dx.doi.org/10.1017/ S0031182099005089. PMid:10633921.

Ribeiro RD, Lopes RA, Albuquerque S, Carraro AA, Satake T, Sala MA, et al. Tripanossomos de peixes brasileiros. XIV. Trypanosoma pradoi sp. n. em Hypostomus ancistroides ihering 1991 (Pisces, Loricariidae), capturado no córrego Laureano, município de Ribeirão Preto, SP, Brasil. Rev da Esc de Farm e Odont de Alf 1993; 15: 36-45.

Ribeiro RD, Lopes RA, Garavello JC, Carraro AA, Albuquerque S, Satake T, et al. Tripanossomos de peixes brasileiros. XXVI. Trypanosoma barrosi sp. n. encontrado no cascudo Hypostomus sp., capturado no rio Tocantins, localidade de Itaguatins, Estado de Goiás, Brasil. An da IX Jor Paul de Parasitol 1992; 1: 16-17.

Ribeiro RD, Lopes RA, Satake T, Nuti A So, Britski HA. Trypanosomes of brazilian fishes. IX. Trypanosoma pintoi sp. n. from armored catfish Hypostomus sp. (Pisces, Loricariidae), from Mogi- Guaçu river, municipality of Pitangueiras, SP, Brazil. Rev Bras Biol 1990a; 50: 559-562.
Ribeiro RD, Lopes RA, Satake T, Nuti-Sobrinho A, Britski HA. Trypanosomes of Brazilian fishes. VIII. Trypanosoma itoi sp. n. from armored catfish Hypostomus sp. (Pisces, Loricariidae), from Moji-Guaçu river, municipality of Pitangueiras, SP, Brazil. Cienc Cult 1990b; 42(12): 1192-1195.

Ribeiro RD, Lopes RA, Satake T, Sala MA, Britski HA. Trypanosomes of brazilian fishes. XIII. Trypanosoma birmani sp. n. from Hypostomus commersonii Valenciènnes 1840 (Pisces, Loricariidae), from Ribeira de Iguape river, SP. Brazil. Acta Biol Leopol 1991; 13: 75-84.

Ribeiro RD, Satake T, Nuti A So, Brentegani LG, Britski HA, Lopes RA. Tripanosomes of brazilian fishes. IV. Trypanosoma lopesi sp. n. from armored catfish Rhinelepis áspera Agassiz 1829 (Teleostei, Loricariidae). Zoo Anz Jena 1989; 222(3-4): 244-248.

Thatcher VE. Amazon fish parasites. 2nd ed. Sofia: Pensoft; 2006. vol. $1,508 \mathrm{p}$.

Woo PTK. Fish diseases and disorders: Protozoan and Metazoan infections. Cambrigde: CAB International; 1995. vol. 1.

Woo PTK. Flagellate parasites of fish. In: Kreier JP. Parasitic Protozoa. New York: Academic Press; 1994. p. 1-180, vol. 8.

Zintl A, Poole WR, Voorheis HP, Holland CV. Naturally occurring Trypanosoma granulosum infections in the European eel, Anguilla anguilla L. from County Mayo, Western Ireland. J Fish Dis 1997; 20(5): 333-341. http://dx.doi.org/10.1046/j.1365-2761.1997.00306.x. 